JPH: Jurnal Pembaharuan Hukum

Volume 8, Number 1, April 2021

\title{
SOCIOLOGICAL ANALYSIS OF NARCOTICS CIRCULATION TREATMENT ON STUDENTS
}

\author{
Andri Winjaya Laksana \\ Sultan Agung Islamic University \\ andriwinjaya@gmail.com
}

\begin{abstract}
Narcotics abuse is a serious problem experienced by various countries including Indonesia. The proliferation of narcotics trafficking among students has become increasingly alarming by making students the target of narcotics syndicates networks. The concern about the circulation of Narcotics among students must be anticipated immediately considering that students are the next generation of the Nation. Juridical empirical approach method. The implementation of the prevention of narcotics crime among students in its development has not been able to run effectively this is because the circulation of narcotics among students with target consumers of fellow students uses social media networking facilities via the internet which is the result of advances in information and communication technology as well as overcoming the circulation of narcotics crime is divided into : primary, before abuse occurs, or known as a preventive function. Usually in the form of education, dissemination of information about the dangers of drugs, approaches through the family, etc. In carrying out this function, the efforts that must be made by the government include regular outreach, establishment of supervisory institutions, forming laws and regulations in various forms, and even establishing international cooperation both bilaterally, regionally and multilaterally.
\end{abstract}

Keywords: Narcotics, Sociological Analysis, Student.

\section{A. INTRODUCING}

Indonesia is a constitutional state based on Pancasila and the 1945 Constitution of the Republic of Indonesia by upholding the moral values, ethics, morals and noble personality of the nation, having faith and fearing God Almighty, and respecting diversity in the life of society, nation and state. and protect the dignity of every citizen. ${ }^{1}$

The state has an important role in making decisions against the perpetrators of criminal acts, namely the perpetrators. The state has taken over the conflict between members of one society and another, so that the violations committed can harm other people and countries through the criminal justice system. ${ }^{2}$

1 Suratman, Andri Winjaya Laksana, Analisis Yuridis Penyidikan Tindak Pidana Pornografi Berdasarkan Undang-Undang Nomor 44 Tahun 2008 Di Era Digitalisasi, Jurnal Pembaharuan Hukum, Volume I No. 2 May-August 2014, page.169-177

2 Andri Winjaya Laksana, Sisca Dyah Octaviani, Implementation of Law Enforcement Against Crime with Small Motive Patterned Restorative Justice In Police Sector Gayamsari Of 
In an increasingly advanced era, the abuse of narcotics is increasingly showing variations where various groups involve in activities that are against the law. A serious problem that is currently being faced is the problem of women's involvement in narcotics abuse, related to this, comprehensive prevention efforts that involve multidisciplinary, multisectoral cooperation and active community participation are needed in a sustainable manner. The development of narcotics abuse from time to time shows an increasing trend that can harm individuals and the surrounding community. Traditionally and modernly, narcotics are widely used for medical purposes. In ancient times, narcotics such as opium served an important role in treating painful human conditions such as diarrhoea, inflammation of the lining of the stomach, and abdominal surgery. Morphine is considered to have strengths over other drugs because it works to treat pain, reduce anxiety and fear, promote sleep, change feelings of discomfort into comfort. At that time, heroin was very important for painkillers and preventing coughs. ${ }^{3}$

The misuse of narcotics, in fact, is a criminal act, so that the perpetrator should carry out a legal process like law enforcement in other criminal cases. The misuse of narcotics includes the qualification of a criminal act (delict) which is regulated in statutory regulations. Criminal law adheres to the principle of legality, as stated in Article 1 paragraph (1) of the Criminal Code which states that: "No act may be punished, but on the strength of the criminal provisions in the law, which is earlier than the act". In criminal law, this principle is known as the "principle of legality", which is a very fundamental principle in Criminal Law because it is a form of protection for individuals, especially perpetrators of criminal acts in ensuring justice and legal certainty. ${ }^{4}$

Currently, drug abuse in Indonesia is very rampant. This can be seen from the increasing number of drug users from all walks of life and the increasing circulation of drugs. However, what is more worrying is the fact that drug abuse is currently mostly among adolescents and young people, namely students. In fact, they are the nation's next generation who will later become leaders in this beloved country. What will happen to this country in the future, with increasingly tough challenges and fierce competition, if the current generation has destroyed itself by using drugs.

Among these students, especially for those who are formally in junior high and high school. Generally, the first drug use begins at elementary school age children or Junior high school. This usually occurs due to offers, persuasion, or pressure from a person or group of people to him, for example by his peers, or it could be prolonged stress, lack of parental attention, a broken home. And at the same time it is driven by curiosity, wanting to try, or wanting to use, someone is willing to accept the offer.

Semarang City, International Journal of Law Recontruction, Volume III, Issue 1, March 2019, page.20-34

3 Yasonna H. Laoly, Jerat Mematikan, Perspektif Kesejahteraan Ekonomi Dalam Penyalahgunaan Narkotika, Cetakan Pertama, Pustaka Alvabet, Ciputat Tangerang, 2019, page. 25.

4 Aulia Fadhli, NAPZA, Ancaman, Bahaya, Regulasi dan Solusi Penanggulangannya, Cetakan Pertama, Gava Media, Yogyakarta, 2018, page. 11-12 
Furthermore, it is not difficult for him to accept the next offer so that it will lead to dependence on the illegal drugs he is using.

Adolescents are a generation that is influential in realising the ideals of a nation, as the next generation and as a generation that is expected by a nation to be able to change the condition of their nation for the better. The development of adolescents today can no longer be proud of and emulated. Current juvenile delinquency behaviour is difficult to monitor and overcome. Recently, we have often heard news in various mass media and in print media about juvenile delinquency, which includes brawls, rape, and naughtiness using narcotics and psychotropic drugs carelessly. ${ }^{5}$

Narcotics are substances or drugs that are very useful and necessary for the treatment of certain diseases. However, if it is misused or used not in accordance with the standard of treatment it can have very detrimental consequences for individuals or society, especially the younger generation. This will be more detrimental if, accompanied by the abuse and illicit trafficking of narcotics which can lead to greater harm. ${ }^{6}$

Drugs are an acronym for narcotics, psychotropic drugs and other addictive substances (Drugs), in general Drugs are chemical substances which, when taken orally (taken, inhaled, inhaled and inhaled) or injected, can affect thoughts, moods, feelings and the behaviour of a person, this can cause a disturbance in social conditions characterised by negative indications, long use time and excessive use. According to medical pharmacology, Narcotics is a drug that can relieve (especially) pain originating from the visceral area and can cause a stupor effect (confused, still conscious and still have to be bluffed) and addiction.?

To more effectively prevent and eradicate the abuse and distribution of narcotics in Indonesia. The government created an institution, namely the National Narcotics Agency (BNN). The BNN is based on Presidential Regulation Number 83 of 2007 concerning the National Narcotics Agency (BNN), the Provincial Narcotics Agency, and the Regency /City Narcotics Agency. Which has the task of coordinating relevant Government agencies in the formulation of policies and implementation of operational policies in the field of availability and prevention, eradication of the abuse and illicit trafficking of Narcotics, Psychotropics, Precursors and other addictive substances, abbreviated as P4GN. And in its implementation, it is assisted by Law Enforcement Officials, namely the Police in their vision and mission as a state instrument that plays a role in maintaining public security and order, upholding the law, and providing protection, protection, and services to the community in the framework of maintaining domestic security.

They are required to carry out their obligations in accordance with the authorities they have in terms of law enforcement as stipulated in Act

5 Andri Winjaya Laksana, Tinjauan Hukum Pemidanaan Terhadap Pelaku Penyalahguna Narkotika Dengan Sistem Rehabilitasi, Jurnal Pembaharuan Hukum, Volume II No. 1 January-April 2015, page.74-85

6 Kaka Alvian Nasution, Himpunan Lengkap Undang-Undang Narkotika dan Psikotropika, Saufa, Jogyakarta, 2014, page.154

7 Widjaya A.W., Masalah Kenalakan Remaja dan Penyalagunaan Narkotika, Armico, Bandung, 2011, page. 145 
No. 2 of 2002 concerning the Indonesian National Police. In handling cases of narcotics misuse in Indonesia the Police always try to eradicate and reveal the circulation of narcotics in Indonesia through Narcotics Investigation Unit (SatResNarkoba) with the ability to investigate and investigate to reveal crimes categorised as extraordinary crimes such as narcotics. ${ }^{8}$

The purpose of this study, to find out and analyze the factors that influence students to abuse narcotics in the city of Semarang, to combat drug trafficking among students in the city of Semarang. The results of this study are expected to be a guide for academics and practitioners (advocates, police, prosecutors, judges) concerns the factors that influence students to abuse Narcotics in Semarang City. Criminal law, or to be able to harmonise the law. Thus, it can support development and development in the world of science, especially regarding the eradication of narcotics abuse.

\section{B. RESEARCH METHODS}

The research approach method on the Sociological Analysis of the Prevention of Narcotics Circulation among Students in the City of Semarang is juridical empirical, namely research by analysing based on facts in the community and data collection. The Empirical Approach is meant as an effort to approach the problem under study with a real legal nature or in accordance with the reality in society regarding the factors that cause narcotics abuse among students and how efforts are made to tackle narcotics crime among students as well as obstacles and solutions in eradicating Narcotics abuse among students in the city of Semarang. Sociological juridical approach, namely research conducted with problem formulation, data collection and analysis design making after the overall process ends with drawing conclusions. ${ }^{9}$

\section{RESULTS AND DISCUSSION}

\section{Narcotics Circulation Among Students in Semarang City in Sociology Perspective}

Indonesia is currently in a state of crisis in the use of illegal drugs. Based on survey results from research by the National Narcotics Agency (BNN) in collaboration with the University of Indonesia Health Research Center in 2018 regarding the development of illegal drug use, it can be seen that the prevalence rate of drug abusers in Indonesia has reached $2.18 \%$ or around 3,8 million to 4.1 million users in the last year (current users) in the age group 10-59 years. Based on the classification of illicit drug cases in 2018, there was a significant increase in the drug case category with an increase of 8.32 from 21,269 cases in 2013 to 23,038 cases in 2018. In the psychotropic group there was a trend of decreasing

8 Tim Citra Umbara, Undang-Undang RI nomor 2 tahun 2002 \& Peraturan Pemerintah RI tahun 2016 tentang Kepolisian, Citra Umbara, Bandung, 2016, page.5

9 Rony Hanitijo, Metode Penelitian Hukum, Ghalia Indonesia, Jakarta, 1994, page.35 
cases, namely by the percentage decreased by $48.01 \%$ from 1,612 cases in 2017 to 838 cases in 2018. ${ }^{10}$

The use of narcotics and illegal drugs (drugs) among adolescents is considered a cause for concern. This is evidenced by the increasing number of adolescents and students who are currently using narcotics. The National Narcotics Agency noted that at the end of 2019 and by 2020 there were 28 percent of adolescents exposed to narcotics users. According to the Commissioner General of Police, Heru Winarko, the spread of narcotics among students in its development has a long impact. This is in the form of use among students and adolescents which is quite long due to their young age.

Until now, the spread of drugs is almost unavoidable. Given that almost all the world's population can easily get drugs from irresponsible people. For example, from drug dealers who like to prey in the area of schools, discotheques, brothels, and places for gang association. Of course this can make parents, mass organisations, the government worry about the spread of drugs that are so rampant. ${ }^{11}$

This is getting more and more complicated with advances in information and communication technology. Nowadays narcotics crime is increasingly being carried out through social media networks, sites in the form of Facebook, Twitter and YouTube are a means for perpetrators to commit crimes, such as selling, purchasing, distributing, and even recruiting narcotics trafficking agents. Transactions through social media are increasingly prevalent and favoured by perpetrators because of the difficulty of detecting crimes committed through social media networks. The social media network system that makes it easy for people to connect with each other makes it easy for the development of narcotics crimes in society. Through friend requests, sharing links, impersonating other people's accounts, disguising products in the form of multivitamins, cosmetics, even in vehicle spare parts packaging, etc. are done to smooth the action of narcotics transactions through social media. In addition, through social media and the lure of high salaries, narcotics dealers recruit couriers to help with the sales and delivery process in the current narcotics transaction process. The phenomenon of social media as a means of spreading Narcotics has triggered an increase in narcotics crime in Indonesia. ${ }^{12}$

This is the reason why Indonesia is one of the countries with a drug emergency. Because now drug users not only from celebrities, businessmen, even students who are still in white and blue uniforms are familiar with and use narcotics. This has brought unrest to the government and society, because the sustainability of this social issue

10 I Gede Darmawan Ardika, I Nyoman Sujana, I Made Minggu Widyantara, Penegakan Hukum Terhadap Penyalahgunaan Tindak Pidana Narkotika, Jurnal Konstruksi Hukum, Vol. 1, No. 2, October 2020, page. 286-290

11 Wahyu Beny Mukti Setyawan. Upaya Pencegahan Terhadap Penyebaran Narkoba Di Kalangan Pelajar, Proseding Seminar Unsa. Vol. 1. No. 1. 2013, page.1-5

12 Mardiana, Pengaruh Media Sosial terhadap Tingkat Pidana Narkotika di Sulawesi Tenggara, Communicatus: Jurnal IImu Komunikasi, Volume 2 Nomor 2 (2018), page.109-122 
can result in damage to social institutions in the community. Various problems are due to the impact of globalisation. According to Mansour Fakih, globalisation is "the process of integrating the national economy into the world economic system with the belief of the free market that was declared during the colonialism era."13 Advances in information, communication and transportation technology that shorten the distance between countries can lead to various national security issues, namely transnational crime, environmental damage, illegal immigrants, pirates, illegal fishing, terrorism, arms smuggling, child trafficking. children and women, drugs, as well as new infections in the form of AIDS, SARS Evian Flu. ${ }^{14}$

This situation was again supported by advances in information and communication technology that reinforced the bodily state crisis. This situation is due to globalisation that has led to a revolution in skills that has increased the capabilities of criminal groups, one of which is narcotics crimes. Head of Public Relations of the National Narcotics Agency (BNN) Senior Commissioner Sumirat Dwiyanto in a report made by VOA said that "Indonesia is one of the largest internet user countries in the world with the number of internet users reaching 40 million people".

Based on the explanation above, it can be seen that the modus operandi in the case of narcotics trafficking has developed, namely:

a. The distribution of narcotics is carried out by students and adolescents with the target consumers of fellow students or adolescents and adults;

b. Narcotics circulation has used social media through the internet, which is the result of advances in information and communication technology.

The spread of narcotics trafficking cases in the city of Semarang is growing rapidly, both in terms of the number of cases and the modus operandi of circulation. This is shown by the availability of data from the Semarang Police Narcotics Detective Unit. In the January-February 2018 period, 47 cases were revealed and this year in the same period, 60 cases were revealed. Furthermore, Bambang Yugo said that "users other than adults who are still of productive age, even become distributors too, there were students yesterday". ${ }^{15}$

Yugo also stated that the latest case involving students was revealed on March 5, 2019 with the suspect named Rico Geger P., where the perpetrator was arrested with evidence of possession of 2 grams of crystal methamphetamine. ${ }^{16}$

13 Mansour Fakih, Sesat Pikir Teori Pembangunan dan Globalisasi, Pustaka Pelajar, Yogyakarta, 2001, page. 210

14 Budi Winarno, Dinamika Isu-Isu Global Kontemporer, PT.Buku Seru, Jakarta, 2014, page. 168-329

15 AKBP Bambang Yugo, Personal interview with Kasat Res Narcotics Police Semarang, Interview conducted on March 1, 2021

16 Ibid. 
In its development, the circulation of narcotics via the internet first appeared after the police arrested a number of people who ordered packages containing drugs online from Malaysia. This drug transaction case is the first case revealed by the police. Sumirat further stated clearly again that: Most of the traffickers of narcotics over the internet use Facebook. The dealers use the Facebook media to place orders, communicate via Facebook, after a long time I have this item and so on. Or they openly opened a kind of "pharmacy", pharmacy-apothecary as if he was selling official drugs. However, the goods must be sent by completely complete goods in the sense that by express package, official deposit, by post or courier and so on. So what needs to be understood is that the internet is only a means of ordering.

In its development related to the definition of the national narcotics law, there are still many regulatory weaknesses both in the Narcotics Law and in other technical regulations such as SEMA and SEJA. This can be seen from the inconsistent use of terms with one another to regulations that are still inclined towards imprisonment, especially for users who are not narcotics dealers.

In practice, the view of addicts and / or victims of narcotics abusers as criminals is still more dominant than the health and healing approach to drug addiction. However, in reality the shift from the viewpoint of prison punishment to a health approach is often put forward by many circles and eventually becomes a trend in other countries.

Then secondly, from the perspective of law enforcement, Indonesia still views the use of narcotics as a criminal act or a legal issue not as a health problem. Including child addicts and / victims of narcotics abuse must face legal problems while their health problems are neglected. Although there have been various kinds of rules regarding children in conflict with the law, such as the Law on the Juvenile Justice System (UU SPPA) and the Child Protection Law, substantively the existing regulations have not fully protected the rights of children of addicts and / victims of conflicting narcotics abusers. By law, the state has put child protection through Act No. 35 of 2014 concerning Amendments to Act No. 23 of 2002 concerning Child Protection. The existence of rules regarding child protection to improve protection for children besides there are also rules regarding the handling of children who commit criminal acts, namely Act No. 11 of 2012 concerning the Criminal Justice System for Children which prioritizes specific treatment of children who commit a crime, either on the rules of the program as well as the judiciary. ${ }^{17}$

Referring to BNN data in 2019, the prevalence of drug abuse among students in 13 provincial capitals in Indonesia reached 3.2 percent or the equivalent of 2.29 million people. Meanwhile, in 2017, the National Narcotics Agency recorded the prevalence rate of narcotics

17 Solehati Nofitasari, Sistem Pemidanaan Dalam Memberikan Perlindungan Bagi Anak Sebagai Pelaku Tindak Pidana, Fairness and Justice: Jurnal Ilmiah IImu Hukum, Vol.14, (No.2) 2016, page.183-219. 
abuse at 1.77 percent or the equivalent of 3,376,115 people in the 10-59 year age range. Then according to the World Drugs Report 2020 published in the End of Year 2020 Press Release, it was noted that there are 271 people who use narcotics in the world, with the age range of users between 15 years and 64 years.

\section{Factors Affecting the Circulation of Narcotics Among Students in the City of Semarang}

Chambliss and Seidman stated that any action that will be taken by stakeholders, implementing agencies and legislators is always within the scope of the complexity of social, cultural, economic and political forces and so on. All social forces always work in every effort to make applicable regulations function, impose sanctions, and in all the activities of the implementing institutions. In the end, the role-played by these legal institutions and institutions is the result of the operation of various factors. ${ }^{18}$

The drug problem in Indonesia is still urgent and complex. In the past decade, this problem has become rampant. This is evidenced by the significant increase in the number of drug abusers or addicts, along with the increasing disclosure of cases of drug crimes with more diverse patterns and more massive syndicate networks. ${ }^{19}$

Substance dependence is a result of severe drug abuse, it is often considered a disease. Addiction, such as the inability to control or stop the use of substances, can cause severe physical harm, if it is stopped, it will be dangerous and detrimental to the family as well as have broad social impacts. One of the factors that influence drug abuse is knowledge, where in a condition if someone knows that what they are going to do will be bad for themselves, then that person will probably not do it. ${ }^{20}$

Factors Affecting the Circulation of Narcotics Among Students in the City of Semarang are:

a. Internal factors, namely factors that come from a person consisting of: ${ }^{21}$

1) Personality If a person's personality is unstable, unfavourable, and easily influenced by others, it is easier to fall into drug abuse.

2) Economy Difficulty finding work creates a desire to work as a drug dealer. A person who is economically well off, but lacks sufficient attention from family or is in the wrong environment is more prone to fall into drug users.

18 William J. Chambliss dan Robert B. Seidman in Esmi Warassih, Pranata Hukum Sebuah Telaah Sosiologis, UNDIP Press, Semarang, 2011, page. 10

19 Maudy Pritha Amanda, Sahadi Humaedi, Meilanny Budiarti Santoso, Penyalahgunaan Narkoba Di Kalangan Remaja (Adolescent Substance Abuse), Jurnal Penelitian \& PPM, Vol 4, No: 2 July 2017, page. 129-389.

20 Qomariyatus Sholihah, Efektivitas Program P4gn Terhadap Pencegahan Penyalahgunaan Napza, Jurnal Kesehatan Masyarakat KEMAS, Vol 9 (1) (2013), page.153-159

21 Dr.Anton Rudiyanto, $\mathrm{SH}, \mathrm{MH}$, Personal interview with the General Criminal Coordinator of the Central Java High Prosecutor's Office, on March 26, 2021. 
b. External factors, namely causal factors that come from outside a person who influence in carrying out an action, in this case drug abuse. External factors themselves, among others:

1) Community Association

Peers have a strong enough influence on the occurrence of drug abuse, usually starting from joining friends, especially for adolescents who have quite weak mental and personality traits.

2) Social / Society

A community environment that is well controlled and has a good organisation will prevent drug abuse from occurring, and vice versa if the social environment that tends to be apathetic and does not care about the surrounding environment can lead to rampant drug abuse among adolescents.

While the factor of narcotics circulation among students in particular can be said to be in the form of: ${ }^{22}$

1) Want to look stylish

Certain types of prohibited substances can make the wearer bolder, cooler, more confident, creative, relaxed, and so on. This cool effect seen by other people can become a trend in certain circles so that people who use banned substances will be called trendy, slang, fashionable, and so on.

2) Group / Community / Gang Solidarity

A group of people who have a high level of kinship between members usually has a high value of solidarity. If the chairperson or several members of the group who are influential in the group use narcotics, then usually the other members, either forcibly or not, will use the narcotics so that they feel like the same fate as the same family.

3) Relieve Pain

Someone who has a disease or disorder that can cause unbearable pain can make people interested in shortcuts to treat their pain, namely by using drugs and illegal substances.

4) Trial or Curiosity

By being attracted to the effects of a prohibited substance, one can have a strong curiosity to taste the pleasure of the forbidden substance. A person can try drugs to just treat his curiosity. Without realising it and being wanted, the person will be addicted and will do it again and again without being able to stop.

5) Follow along

People who have become victims of drugs may try to invite other people who have not been contaminated with drugs so that other people can share the sensation or suffering they feel. Traffickers and users may give away drugs for free as an introduction and will charge a fee after the victim is hooked.

22 Brigjen Pol (Purn) Simson Sugiarto, Personal interview with the Head of the Department of Community Service and Community Service for the National Anti-Narcotics Movement, on February 12, 2021. 
6) Resolving and Forgetting Problems / Burdens

Stress People who are hooded with many problems and want to run away from problems can fall into the lap of narcotics, drugs or addictive substances in order to sleep soundly, get drunk, or feel the excitement that arises which is the effect of the use of certain substances.

7) Accentuating the Rebellious Side or Feeling Great.

A person who is naughty or evil generally wants to be seen by others as a person who is feared so that all his wishes can be fulfilled. The prohibited substance will help shape the unusual and rebellious attitudes and behaviours of the existing order. Users who want to be considered great by their friends can fall into prohibited substances.

8) Eliminate Feeling Tired and Bored.

Boredom, discomfort and so on for some people is something that is unpleasant and wants to be removed from the mind immediately. Prohibited substances can help someone who is having a lot of thoughts to get over the boredom that has hit. A person can pursue pleasures by using illegal drugs which lead to pleasant hallucinations and delusions.

9) Looking for Challenges or Risk Activities.

For people who are happy with activities that have a high risk of carrying out their actions there are those who use illegal drugs to become the greatest, full of energy and full of confidence.

10)Feeling Mature

Young users of illegal substances sometimes want to be considered adults by others in order to live freely, so they commit substance abuse. By becoming an adult as if one can act at will, feel ripe, free from the rules and supervision of parents, teachers, etc.

In the midst of a situation of increasing crime of narcotics abuse, it is feared that it will potentially become a carcinogenic factor in the emergence of criminal acts of narcotics abuse. Because the effectiveness of the enactment of law in society is often determined by how the law is implemented in a concrete manner by law enforcers. Therefore, it is not enough to tackle a crime if it only relies on the formation of good laws and regulations, but it must also be followed by consistent implementation steps by all components of law enforcement. ${ }^{23}$ Basically, the problems of the state are also our problems, the connection with the enforcement of the rule of law is the biggest and most pressing problem of the Indonesian state, so it is very appropriate that our criticism of these legal problems must also be accompanied by alternative solutions.

23 Mustating DG Maroa, Penegakan Hukum Dalam Penanggulangan Tindak Pidana Penyalahgunaan Narkotika Di Kabupaten Banggai, Jurnal Yustisiabel, Volume I Nomor I April 2017, page.56-68 
One of the crimes that are currently attracting the attention of the public and many occur in Indonesia is the crime of narcotics abuse. The crime of narcotics abuse is a very serious problem, because the crime of narcotics abuse can threaten the health and even the life of the person who commits it. Narcotics crime has penetrated all levels of society, both from the middle to lower and upper middle classes. The rise of criminal cases of narcotics abuse in Indonesia lately is due to a wide network of narcotics dealer syndicates that require optimal efforts to eradicate the narcotics trafficking network to its roots. ${ }^{24}$

The distribution of narcotics in schools does not recognise discrimination and does not only enter public schools. Syndicates approach students by experiencing it free for the first time. After the victim is lulled into using the pleasure of narcotics using illegal drugs, narcotics are no longer obtained for frees, using the offer so that the student would want to help them offer the drugs to their school friends. if you agree, then not only free drugs are obtained, but also a certain amount of money in return. The modus operandi that has also occurred, the trend is to carry out drug trafficking using various school equipment such as pens, books, erasers and so on to create a process of dependence on narcotics. ${ }^{25}$

\section{CONCLUSION}

The implementation of the prevention of narcotics crime among students in its development has not been able to run effectively this is because the circulation of narcotics among students with target consumers of fellow students uses social media networking facilities via the internet which is the result of advances in information and communication technology as well as overcoming the circulation of narcotics crime is divided into : primary, before abuse occurs, or known as a preventive function. Usually in the form of education, dissemination of information about the dangers of drugs, approaches through the family, etc. In carrying out this function, the efforts that must be made by the government include regular outreach, establishment of supervisory institutions, forming laws and regulations in various forms, and even establishing international cooperation both bilaterally, regionally and multilaterally.

24 Cakra Rismanda, Rehnalemken Ginting, Faktor-Faktor Penyebab Tindak Pidana Penyalahgunaan Narkotika Di Kota Surakarta, Recidive, Volume 7 No. 1, January-April 2018, page.31-40

25 Novi Novitasari, Nur Rochaeti, Proses Penegakan Hukum Terhadap Tindak Pidana Penyalahgunaan Narkotika Yang Dilakukan Oleh Anak, Jurnal Pembangunan Hukum Indonesia, Volume 3, Nomor 1, 2021, page.96-108 


\section{BIBLIOGRAPHY}

\section{Books:}

Aulia Fadhli, 2018, NAPZA, Ancaman, Bahaya, Regulasi dan Solusi Penanggulangannya, Cetakan Pertama, Gava Media, Yogyakarta;

Budi Winarno, 2014, Dinamika Isu-Isu Global Kontemporer, PT.Buku Seru, Jakarta;

Esmi Warassih, 2011, Pranata Hukum Sebuah Telaah Sosiologis, UNDIP Press, Semarang;

Kaka Alvian Nasution, 2014, Himpunan Lengkap Undang-Undang Narkotika dan Psikotropika, Saufa, Jogyakarta;

Mansour Fakih, 2001, Sesat Pikir Teori Pembangunan dan Globalisasi, Pustaka Pelajar, Yogyakarta;

Rony Hanitijo, 1994, Metode Penelitian Hukum, Ghalia Indonesia, Jakarta;

Tim Citra Umbara, 2016, Undang-Undang RI nomor 2 tahun 2002 \& Peraturan Pemerintah RI tahun 2016 tentang Kepolisian, Citra Umbara, Bandung;

Widjaya A.W., 2011, Masalah Kenalakan Remaja dan Penyalagunaan Narkotika, Armico, Bandung;

Yasonna H. Laoly, 2019, Jerat Mematikan, Perspektif Kesejahteraan Ekonomi Dalam Penyalahgunaan Narkotika, Cetakan Pertama, Pustaka Alvabet, Ciputat Tangerang;

\section{Journals:}

Bambang Tri Bawono, The Strategy For Handling Corruption's Criminal Action Relationship To Saving Of State Financial Losses, Jurnal Pembaharuan Hukum, Vol 7, No 3, December 2020;

Andri Winjaya Laksana, Tinjauan Hukum Pemidanaan Terhadap Pelaku Penyalahguna Narkotika Dengan Sistem Rehabilitasi, Jurnal Pembaharuan Hukum, Volume II No. 1 January-April 2015;

Andri Winjaya Laksana, Sisca Dyah Octaviani, Implementation of Law Enforcement Against Crime with Small Motive Patterned Restorative Justice in Police Sector Gayamsari Of Semarang City, International Journal of Law Recontruction, Volume III, Issue 1, March 2019;

Cakra Rismanda, Rehnalemken Ginting, Faktor-Faktor Penyebab Tindak Pidana Penyalahgunaan Narkotika Di Kota Surakarta, Recidive, Volume 7 No. 1, January-April 2018; 
I Gede Darmawan Ardika, I Nyoman Sujana, I Made Minggu Widyantara, Penegakan Hukum Terhadap Penyalahgunaan Tindak Pidana Narkotika, Jurnal Konstruksi Hukum, Vol. 1, No. 2, October 2020;

Mardiana, Pengaruh Media Sosial terhadap Tingkat Pidana Narkotika di Sulawesi Tenggara, Communicatus: Jurnal IImu Komunikasi, Volume 2 Nomor 2 (2018);

Maudy Pritha Amanda, Sahadi Humaedi, Meilanny Budiarti Santoso, Penyalahgunaan Narkoba Di Kalangan Remaja (Adolescent Substance Abuse), Jurnal Penelitian \& PPM, Vol 4, No: 2 July 2017;

Mustating DG Maroa, Penegakan Hukum Dalam Penanggulangan Tindak Pidana Penyalahgunaan Narkotika Di Kabupaten Banggai, Jurnal Yustisiabel, Volume I Nomor I April 2017;

Novi Novitasari, Nur Rochaeti, Proses Penegakan Hukum Terhadap Tindak Pidana Penyalahgunaan Narkotika Yang Dilakukan Oleh Anak, Jurnal Pembangunan Hukum Indonesia, Volume 3, Nomor 1, Tahun 2021

Qomariyatus Sholihah, Efektivitas Program P4gn Terhadap Pencegahan Penyalahgunaan Napza, Jurnal Kesehatan Masyarakat KEMAS, Vol 9 (1) (2013);

Solehati Nofitasari, Sistem Pemidanaan Dalam Memberikan Perlindungan Bagi Anak Sebagai Pelaku Tindak Pidana, Fairness and Justice: Jurnal IImiah IImu Hukum, Vol.14, (No.2) 2016;

Suratman, Andri Winjaya Laksana, Analisis Yuridis Penyidikan Tindak Pidana Pornografi Berdasarkan Undang-Undang Nomor 44 Tahun 2008 Di Era Digitalisasi, Jurnal Pembaharuan Hukum, Volume I No. 2 MayAugust 2014;

Wahyu Beny Mukti Setyawan. Upaya Pencegahan Terhadap Penyebaran Narkoba Di Kalangan Pelajar, Proseding Seminar Unsa. Vol. 1. No. 1. 2013; 